\title{
PIRACY IN LIGHT OF MARINE INSURANCE LAW WITH A VIEW OF RANSOM PAYMENTS
}

Dino Gliha, mag. iur.*

\author{
UDK 347.799.4 \\ https://doi.org/10.30925/zpfsr.39.2.5 \\ Ur.: 11. rujna 2017. \\ Pr.: 20. studenoga 2017. \\ Izvorni znanstveni rad
}

\begin{abstract}
Summary
After the 2008 Somali attacks, piracy has gained significant popularity among scholars. However, despite lots of ongoing debates and written papers in the last decade, some crucial issues have been left unresolved, starting from the definition of piracy. When discussing piracy within the context of marine insurance, certain specific characteristics of marine insurance law should be taken into consideration. Namely, international law definition, criminal law definition and other definitions of piracy cannot properly satisfy the need of marine insurance law. After the proper understanding of piracy within marine insurance law is determined, there are some other important issues that need to be discussed. Certainly, one is categorization of piracy as a peril. Question whether piracy is a marine peril or a war peril? Further on, one of the most discussed issue of modern piracy are ransom payments. Can they even be considered legal? If yes, are they recoverable from marine insurers and on which basis? Answers to previously mentioned questions will be given in the following paper.
\end{abstract}

Keywords: $\quad$ marine insurance, piracy, definition of piracy, maritime perils, ransom payments.

\section{INTRODUCTION}

When talking about piracy, people tend to imagine primitive group of people on a wooden sailer, armed with swords with a captain wearing a black eyepatch and having a hook on his arm. Well, that was maybe a case back in the $18^{\text {th }}$ and $19^{\text {th }}$ century, ${ }^{1}$ however nowadays pirates have become more sophisticated and evolved along with the rest of the civilization. Instead of sailing on old wooden vessels they sail organized on speed skiffs, instead of carrying swords they carry automatic rifles and rocket-propelled grenades. ${ }^{2}$

* Dino Gliha, mag. iur., odvjetnički vježbenik; dino.gliha@gmail.com.

1 Some authors at the beginning of $20^{\text {th }}$ century believed that by the end of $19^{\text {th }}$ century piracy has ended forever. Philip Gosse, The History of Piracy, New York, 1934.

2 Yvonne M. Dutton, Jon Bellish, Refusing to Negotiate: Analyzing the Legality and Practicality 
When act of piracy occurs, it is not likely that it will end just on an attack. Usually it is followed by hijacking, negotiations, and ultimately a ransom demand. Considering all, it affects numerous different subjects of sailing venture and involves various areas of law. From criminal, over international to civil law. One of the most specific area involved in act of piracy is marine insurance law. However, especially in this area of law there are still lots of questions that need to be resolved, starting from the bare definition of term piracy.

Law has not provided one unique definition of piracy that will universally satisfy all of the areas of law. There are numerous different understandings on this specific notion. Marine insurance law is developing it's understanding through case law of competent courts and practice of marine insurers. However, there are still significant unevenness and it is crucial to provide unique and stable understanding of this institute in order to deal with some of the existent issues of piracy within marine insurance law.

One of them is certainly understanding of marine insurance as a peril; determination whether it is maritime peril or war and strike peril. Practice, scientific papers and case law have provided some opposite understandings on this matter. In order to resolve some potential disputes on whether or not a certain act of piracy is involved in certain insurance policy it is necessary to discuss this issue. Namely, it is common practice that maritime perils and war and strike perils are excluded from same policies.

Further on, piracy ransom payments have caused lots of debates within marine insurance law. Although, ransom payments are quite common in cases of pirate attacks it is questionable if they are even allowed and legal in modern regulated legal systems. Also, the treatment of respective payments is disputable under the marine insurance law. On which basis could they be recovered and from which insurer premium insurers or P\&I clubs? Could they be treated as a general average or as a sue and labour cost. Moreover, considering that there are more interested participants of maritime ventures who would have an interest to preserve their valuables, it can be discussed who will be the one that will pay the ransom and from who could he or his insurer recover from?

Finally, it is important to point out one specific phenomenon of marine insurance law. Considering the specific nature of marine insurance, throughout this paper the accent shall be on English law and practice. Namely, due to the lack of universally accepted regulation it is common that marine insurance contracts are governed expressly or impliedly by English law, even though none of the contracting parties are in a direct relation with the English legal system. This is completely justified given that in marine insurance law the general rule for determining governing law is the principle of party autonomy. ${ }^{3}$ Reason for broad usage of English law lies in the traditionally developed practice of English insurers and courts, and the fact that much of the world's marine insurance business is transacted in London. ${ }^{4}$

of a Piracy Ransom Ban, Cornell International Law Journal, Vol. 47, pp 299-329, p. 305.

3 Drago Pavić, Pomorsko imovinsko pravo, Split, 2006, p 524.

4 Marko Pavliha, Overview of Marine Insurance Law, IMO International Maritime Law Institute, Malta, $7^{\text {th }}-10^{\text {th }}$ January 2013 , available at: http://www.google.hr/url? sa $=t \& r c$ $\mathrm{t}=\mathrm{j} \& \mathrm{q}=\& \operatorname{esrc}=\mathrm{s} \&$ source $=$ web $\& \mathrm{~cd}=3 \& \mathrm{ved}=0$ ahUKEwjciNmN-YrSAhWqIJoKHRpkB- 


\section{LEGAL ASPECTS OF PIRACY: DEFINITION AND CHARACTERISTICS}

Before introducing a closer examination of certain specific legal aspects of piracy in marine insurance law, a few general remarks about piracy are to be made. Primarily, the definition of the notion of piracy and identification of its general characteristics in comparison to other similar acts of violence shall be presented.

\subsection{Definition and characteristics of piracy in marine insurance law}

Piracy as an act has inflicted maritime since the earliest times in history. Thus, when analysing definition of piracy, it's roots should be looked up in early history. The Ancient Greek had two common words with meaning close to piracy as known today - leiestes and peirates. Leiestes is derived from the same root as word leis meaning booty or plunder, which would correspond to today's words pirates and bandits. Peirates is of later date in ancient Greek's vocabulary and its meaning is synonymous with word leistes, with a difference that it derives from word peira which means trial or attempt. ${ }^{5}$

Throughout the history piracy has evolved as a legal as well as economic institute and has been recognized in various areas of expertise. There are, therefore, different understandings of piracy such as an international law understanding of piracy, criminal law understanding of piracy, international shipping industry understanding of piracy, common law understanding of piracy and insurance industry understanding of piracy. ${ }^{6,7}$

According to Art 15 of the 1958 United Nations Convention on the High Sea

AQFggpMAI\&url=http $\% 3 \mathrm{~A} \% 2 \mathrm{~F} \% 2 \mathrm{Fwww} . \mathrm{dpps}-\mathrm{mlas} . \mathrm{si} \% 2 \mathrm{Fwp}-$ content $\% 2 \mathrm{Fupload}$ s\%2F 2012\%2F12\%2FOverview-of-Marine-Insurance-Law-Prof.-dr.-Marko-Pavliha. doc\&usg=AFQjCNF73RTdPBYnbIhDcRUDbEcUVAHu4Q (last accessed: 13.02.2017.).

5 Philip de Souza, Piracy in the Graeco-Roman World, Cambridge, 2002, pp 2-13.

6 Michael H. Passman, Interpreting Sea Piracy Clauses in Marine Insurance Contracts, Journal of Maritime Law \& Commerce, Vol. 40, No. 1, January, 2009, pp 59-88, p 61.

7 Rubin suggests that there are at least six different meanings of piracy: (1) A vernacular usage with no direct legal implications; (2) An international law meaning related to unrecognized states or recognized states whose governments are not considered to be empowered at international law to authorize the sorts of public activity that is questioned, like the Barbary States of about 1600-1830, the Malay Sultanates of about 1800-1880, and the Persian Gulf Sheikhdoms of about 1820-1830; (3) An international law meaning related to unrecognized belligerency, like Confederate States commerce raiders and privateers during the American Civil War of 1861-65 in the eyes of the Federal Government of the United States; (4) An international law meaning related to the private acts of foreigners against other foreigners in circumstances making criminal jurisdiction by a third state acceptable to the international community despite the absence of the usual territorial or nationality links that are normally required to justify the extension abroad of national criminal jurisdiction; (5) Various special international law meanings derived from particular treaty negotiations; and (6) Various municipal (i.e., national, domestic) law meanings defined by the statutes and practices of individual states.; Alfred P. Rubin, The Law of Piracy, Newport, 1988, p. 1.

8 United Nations Convention on the High Sea, 29 April 1958, 13 UST 2312; 450 UNTS 11, 
and Art 101 of the 1982 United Nations Convention on the Law of the Sea (hereinafter: UNCLOS), ${ }^{9}$ which both have adopted the same definition of piracy, piracy consists of the following acts:

(1) Any illegal acts of violence, detention or any act of depredation, committed for private ends by the crew or the passengers of a private ship or a private aircraft, and directed:

(a) On the high seas, against another ship or aircraft, or against persons or property on board such ship or aircraft;

(b) Against a ship, aircraft, persons or property in a place outside the jurisdiction of any State;

(2) Any act of voluntary participation in the operation of a ship or of an aircraft with knowledge of facts making it a pirate ship or aircraft;

(3) Any act of inciting or of intentionally facilitating an act described in subparagraph 1 or subparagraph 2 of this article.

From the above cited definition, several essential characteristics can be derived that define an act of piracy with regard to international law; that it constitutes an illegal act of violence, detention or depredation, committed for non-public and non- political goals by the crew or passengers of private ship against another ship or persons or property on such ship,$^{10}$ committed on the high seas or places outside the jurisdiction of any state. When using this definition of piracy, one must have in mind that it is primarily drafted to create universal jurisdiction in order to capture and prosecute pirates, in non-jurisdiction areas. All this in order to preserve peace and strengthen cooperation and friendly relations among all nations in conformity with the principles of justice and equal rights and promotion of the economic and social prosperity of all peoples of the world. ${ }^{11}$ It can be, therefore, concluded that international law's understanding of piracy defines the so-called notion of absolute piracy, contrary to relative piracy which designates acts of piracy within boarders of national jurisdictions. ${ }^{12}$

Considering the contractual nature of marine insurance, this technical and highly specific definition of piracy is not useful where courts seek to enforce reasonable expectations of the parties..$^{13}$ Further on, international law definition of piracy excludes acts of piracy committed within territorial seas of states which can lead to serious problems in practice especially having in mind inter partes relationship of the parties

available at: http://www.gc.noaa.gov/documents/8_1_1958_high_seas.pdf.

9 United Nations Convention on the Law of the Sea, 10 December 1982, 1833 UNTS 3; 21 ILM

1261 (1982), available at: http://www.un.org/depts/los/convention_agreements/texts/unclos/ unclos_e.pdf.

10 The international law definition of piracy requires that two ships must be involved. Attack launched from land, dock or even water cannot constitute a pirate attack. Hodgkison, S. L., The Governing International Law on Maritime Piracy, in: Scharf, M. P. (ed.), Newton, M. A. (ed.)., Sterio, M. (ed.), Prosecuting Maritime Piracy: Domestic Solutions to International Crimes, 2015, p. 21.

11 Art. 100 in accordance with the Preamble of the UNCLOS.

12 Pospišil, M., Somalsko piratstvo - od vojnopomorskih operacija do naoružanja brodova, Zbornik radova Pravnog fakulteta u Splitu, yr. 49, no 1/2012, p. 69.

13 Michael H. Passman, op. cit., n. 6, p. 70. 
to a marine insurance agreement. In such case if the attacked ship has a nationality the attack would obtain its territorial attribute from the nationality of that ship in the same way in which jurisdiction can be attributed to the flag state of the attacked vessel in terms of the 1988 Convention for the Suppression of Unlawful Acts of Violence against the Safety of Maritime Navigation (SUA Convention) ${ }^{14} \cdot{ }^{15}$

Contrary to international law definition of piracy, the institute of piracy in criminal law has its numerous definitions. Regardless of international character of piracy as a crime, different states regulate institute of piracy differently. While some have accepted international law definition of piracy in their statutes, others have their own definitions. ${ }^{16}$ This leads to one serious problem of determining which nation's definition should apply in a specific case. Although this problem can be overcome by use of choice-of-law rules, using only one of many possible criminal law definitions of piracy seems rather imprudent in marine insurance context since it also violates the principle of reasonable expectations. It would be unlikely to expect from the parties to the marine insurance contract, regardless of their experience, to be familiar with foreign criminal law statutes on that matter. ${ }^{17}$ This is especially the case in commercial law where everything should be done with extremely high efficiency and without any unnecessary delays.

International shipping industry has also provided its own definition of piracy primarily through the International Chamber of Commerce International Maritime Bureau's Piracy Reporting Centre (hereinafter: IMB PRC). ${ }^{18}$ Throughout its reports and mainly for statistical purposes, IMB PRC has created the following non-legal definition of piracy: An act of boarding or attempting to board any ship with the apparent intent to commit theft or any other crime and with the apparent intent or capability to use force in the furtherance of that act. Such definition of piracy has been adopted by the IMB since the majority of attacks against ships take place within the jurisdictions of certain States, and piracy as defined under United Nations Convention on Law of the Sea (1982) does not address that aspect. ${ }^{19}$ IMB PRC's definition of piracy is undoubtfully useful but it is not based on any legal precedent and it is not

14 Convention for the Suppression of Unlawful Acts against the Safety of Maritime Navigation, March 10, 1988, 27 ILM 668 (1988); 1678 UNTS 221 available at: http://www.un.org/en/sc/ ctc/docs/conventions/Conv8.pdf.

15 Gotthard Gauci, Piracy and its Legal Problems: With Specific Reference to the English Law of Marine Insurance, Journal of Maritime Law \& Commerce, Vol. 41, No. 4, October, 2010, pp 541-560, p 549.

16 Passman, M. H., op. cit., n. 6, p. 70.- 72.

17 Ibid., p. 72.

18 IMB PRC is an independent and non-governmental agency established in 1992 and based in Kuala Lumpur. Its aim is to raise awareness within the shipping industry of high risk areas with pirate attacks and specific ports/anchorages where armed robberies on board ships have occurred. IMB PRC offers a 24-hour and free service for shipmasters to report any piracy, armed robbery or stowaway incidents. Available at: https://www.icc-ccs.org/piracy-reportingcentre, February 05, 2017.

19 ICC International Maritime Bureau Piracy and Armed Robbery Against Ships Annual Report, 1 January - 31 December 2007, <http://www.rk-marine-kiel.de/files/piraterie/imb/imb_piracy_ report_2007.pdf>, February 05, 2017, p. 2. 
appropriate for marine insurance purposes. ${ }^{20}$

Common law has defined piracy as those acts of depredation and robbery committed on the high seas which, if committed on land, would have amounted to a felony. ${ }^{21}$ Although this definition is not entirely suitable for marine insurance needs in cases of piracy, it has become somewhat popular in the common usage and the case law, including marine insurance cases interpreting piracy clauses. Furthermore, similar definition is being used by some law dictionaries, such as Black's Law Dictionary ${ }^{22}$ that is commonly used by courts when seeking for definitions of law institutes. ${ }^{23}$

Although the above-mentioned definitions have their own values and purposes, marine insurance definition should be distinguished thereof due to a specific contractual nature of marine insurance. Therefore, certain principles and needs should be satisfied in order to properly define piracy within the marine insurance.

Further to the above-stated, interpretation of the meaning of piracy in marine insurance contracts implicates three important contract doctrines that were developed primarily through case law of Courts in the United Kingdom and United States: 1) reasonable expectations, 2) usage of trade, and 3) contra proferentem..$^{24}$ Under the doctrine of reasonable expectations, courts interpret marine insurance contracts to provide the coverage that the insured reasonable assume they had purchased. When interpreting piracy within marine insurance law pursuant to doctrine of reasonable expectations, courts should look to the parties' expectations in the meaning of terms while appropriately considering the relative sophistication of parties. ${ }^{25}$ Application of doctrine of usage of trade means that the courts should deal with a key issue of whether to look to the insurance industry or shipping industry for the proper usage of trade. ${ }^{26}$ Finally, contra proferentem doctrine implies that ambiguous terms in the contract are to be construed against the drafter, which in terms of marine insurance means that the insurers have generally much more powerful bargaining position than the insured. ${ }^{27}$

Moreover, as previously stated, a term piracy in marine insurance law should also include acts of piracy committed in territorial waters. International law definition of piracy is drafted to create a universal jurisdiction to sustain acts of piracy in nonjurisdiction areas. Regarding the contractual nature of marine insurance, international law's determination of universal jurisdiction to seize ships on high seas has its purpose in marine insurance law; piracy here should thus be understood in both absolute and relative terms.

20 Passman, M. H., op. cit., n. 6, p. 68.

21 East, E. H., A Treatise of the Pleas of the Crown, Vol. II, Philadelphia, 1806, p. 796.; In Re a Reference under the Judicial Committee Act, 1833, In Re Piracy Jure Gentium. The American Journal of International Law, Vol. 29, No. 1, 1935, p. 140-150.

22 Black's Law Dictionary Free Online Legal Dictionary $2^{\text {nd }}$ Ed., <http://thelawdictionary.org/ piracy>, February 05, 2017.

23 Passman, M. H., op. cit., n. 6, p. 73.

24 Ibid. p. 62-63.

25 Ibid. p. 63-64.

26 Ibid. p. 64-65.

27 Ibid. p. 65-66. 
In this regard and from the marine insurance aspect, it is important to set equal standards when act of piracy is committed on an insured object, regardless of whether that object is in the territorial or non-territorial waters. The next step would be to create unique definition of piracy that would satisfy the needs of marine insurance law and could be applicable universally regardless of the differences that arise from various legal systems.

\subsection{Piracy and similar acts of violence}

In order to provide proper definition of piracy in context of marine insurance law, it is also important to point at the differences between piracy and certain other similar acts that could be misjudged as an act of piracy and which sometimes only differ from piracy due to internal motivation in conduction of a certain act.

\subsubsection{Politically motivated acts}

One of them are certainly politically motivated acts that can imitate acts of piracy. But, as explicitly stated in UNCLOS international law definition of piracy, pirate acts are considered to be illegal acts of violence, detention or any act of depredation, committed for private ends (...). Therefore, it should be clear that politically motivated acts cannot be considered as being committed for private ends since they imply public interest. However, practice has brought out different interpretations of term for private ends, necessary for determining whether certain act falls within the scope of definition of piracy. ${ }^{28}$

Considering historical context, term "for private ends" was mainly introduced with the purpose of all states having a universal jurisdiction to pursue their interests at sea and to exclude insurgent and independence movements that could become recognized states. International subjects as such should not fall within that kind of jurisdiction due to potential abuse. ${ }^{29}$ The position of other political actors, such as environmental activists in previous cases, was not established and was left in the grey area of application and conflicting interpretation that stayed unresolved until present times. ${ }^{30}$

One of the most controversial decisions on the interpretation of notion private ends was the US Federal Ninth Circuit Court decision in case Institute of Cetacean Research $v$ Sea Shepherd Conservation Society. ${ }^{31}$ In this case, attack of the group of international non-profit marine conservation wildlife organization on a ship that

28 Honnibal, A. N., The 'Private Ends' of International Piracy: The Necessity of Legal Clarity in Relation to Violent Political Activists, International Criminal Database, Brief 13, October 2015, <http://www.internationalcrimesdatabase.org/upload/documents/20151102T100953Honniball\%20ICD\%20Brief.pdf>, p. 3-5.

29 Matsuda, M., Wang Chung-Hui, M., Questionnaire No. 6: Piracy, The American Journal of International Law, vol. 20, no. 3, 1926, p. 222-229.

30 Honnibal, A. N., op. cit. n. 28, p. 5-10.

31 United States Court of Appeals for the Ninth Circuit, case Institute of Cetacean Research $v$. Sea Shepherd Conservation Society, <https://www.ca9.uscourts.gov/content/view.php?pk id $=0000000655>$, February 05, 2017. 
carried a group of Japanese researchers who hunted whales, was considered to be piratical. What turned up to be controversial was the Opinion of judge Kozinski where he considered acts taken for private ends as those not taken on behalf of a state. ${ }^{32} \mathrm{He}$ further explained the following:

We conclude that "private ends" include those pursued on personal, moral or philosophical grounds, such as Sea Shepherd's professed environmental goals. That the perpetrators believe themselves to be serving the public good does not render their ends public. ${ }^{33}$

The Court has hereby decided that political protesters could commit piracy if they crossed the line into violent protest, ${ }^{34}$ whereas interpreting what is considered to be public very restrictively. The main grounds for this kind of interpretation the Court found in Belgian case of Castle John ${ }^{35}$ where environmental group Greenpeace engaged piratical attacks on private vessels to alert the public to the danger of discharging waste from vessel into the sea. ${ }^{36}$ In the mentioned case Belgian Cour de Cassation held that environmental activism qualifies as a private end with the following explanation:

The applicants do not argue that the acts at issue were committed in the interest or detriment of a State or a State system rather than purely in support of a personal point of view concerning a particular problem, even if they reflected a political perspective [...] the Court of Appeal was entitled to decide that the acts at issue were committed for personal ends (emphasis added). ${ }^{37}$

However, evidence and argumentation that Courts provided in previous decisions were not sufficient enough to convince that this kind of acts could fall within the concept of piracy. It completely neglected motivation for conducting piratical attack as one of the crucial elements when deciding whether some act is piratical or not. According to international law definition of piracy, an act of piracy must be committed by a private ship ${ }^{38}$ for private ends against another ship. Although attacked ship does not have to be private, it can be assumed that the definition of piracy cannot be fulfilled when a governmental or other public interest ship is attacked. However,

32 United States Court of Appeals for the Ninth Circuit, case Institute of Cetacean Research v. Sea Shepherd Conservation Society, Opinion of Judge Kozinski, from February 25, 2013, <http:// cdn.ca9.uscourts.gov/datastore/general/2013/02/25/1235266.pdf>, February 05, 2017.

33 Ibid.

34 Guilfoyle, D., Political Motivation and Piracy: What History Doesn't Teach Us About Law, Blog of the European Journal of International Law, June 17, 2013, <http:/www.ejiltalk.org/ political-motivation-and-piracy-what-history-doesnt-teach-us-about-law/>, February 05, 2017.

35 Belgium Cour de Cassation, case Castle John and Nederlandse Stichting Sirius v. NV Mabeco and NV Parfin, December 19, 1988, 77 ILR 537.

36 Honnibal, A. N., op. cit. n. 28, p. 8.

37 Castle John and Nederlandse Stichting Sirius v. NV Mabeco and NV Parfin, op. cit. n. 35, p. 540.

38 However, acts of piracy committed by a government ship or a government aircraft whose crew has mutinied and taken control of the ship or aircraft are assimilated to acts committed by a private vessel.; Johnson, D. H. N., Piracy in Modern International Law, Transactions of the Grotius Society, Vol. 43, Problems of Public and Private International Law, Transactions for the Year 1957 (1957), p. 66. 
in case of political activists pursuing private ships, motivation should also be taken into consideration, especially with respect to traditional concept of piracy. According to traditional concept of piracy, term private ends involves either actions for gain or those committed with animo furandi - a wilful desire to inflict injury on others. On the other hand, non-private ends are not specifically defined. Therefore, it is accepted that non-private ends include actions undertaken under control of a lawful privateering commission issued by a recognized power. ${ }^{39}$

In later procedure in Notice of Filing of Petition for Certiorari, ${ }^{40}$ Defendant (Petitioner) has argued that the Ninth Circuit Court in Institute of Cetacean Research $v$ Sea Shepherd Conservation Society case has neglected some crucial facts that exclude environmental activists as non-state politically motivated group from the definition of piracy. Thus, from the historical aspect during negotiations over the High Seas Convention, Czechoslovakia objected to the proposed private ends clause, because it excluded acts of piracy committed for political ends.$^{41}$ Further on, there are numerous scholarly works which conclude that the "private ends" language excludes acts in furtherance of environmental and other political goals. ${ }^{42}$

Moreover, it is clear that marine insurers have reached an understanding that - as far as they are concerned - politically motivated acts are clearly distinguished from piracy acts. For instance, in clause 1.5. of War and Strikes Clauses Hulls-Time clause, ${ }^{43}$ coverage is provided to vessels that suffer loss or damage caused by any person acting from a political motive (...). Acts of piracy are explicitly excluded in clause 5.1.6. and are covered by Institute Time Clauses - Hulls ${ }^{44}$ clauses in clause 6.1.5. This kind of wording is closer to understanding that political activists' acts would rather fall under War and Strikes insurance coverage than under coverage for piracy, which is explicitly excluded from War and Strikes coverage.

As from the international law standpoint, marine insurance law also needs universally accepted interpretation of private ends. Without such clear interpretation, lack of certainty may only bring further potential complications. Until that happens, though, marine insurers should consider opposition between public and private in piracy in the following way; when a private ship commits an act with elements of piracy against other ship owned or controlled by the government, there should be a presumption that attack should not fall within the definition, especially if attack was

39 Menneffe, S. P., The Case of the Castle John or Greenbeard the Pirate?: Environmentalism, Piracy and the Development of International law, California Western International Law Journal, Vol. 24, No 1, Fall 1993, p. 4.

40 Supreme Court of the United States, case Institute of Cetacean Research v Sea Shepherd Conservation Society, Notice of Filing of Petition for Certiorari, April 30, 2015, http://cdn.ca9. uscourts.gov/datastore/general/2015/05/05/12-35266\%20Cert\%20Notice.pdf, February 05, 2017.

41 Ronzitti, N., The Law of the Sea and Use of Force Against Terrorist Activities, in: Natalino Ronzitti, (ed), Maritime Terrorism and International Law, Dordrecht, 1990, p. 2.

42 Azubuike, L., International Law Regime Against Piracy, Annual Survey of International and Comparative Law, Vol. 15, No. 1, 2010, p. 52; Bantekas, I., Nash, S., International Criminal Law, $2^{\text {nd }}$ ed, London, 2003, p. 98.

43 Institute War and Strikes Clauses, Hulls - time, 1/11/95.

44 Institute Time Clauses - Hulls, 1/11/95. 
pursued with a clear political motivation. Conversely, in "grey" cases where act with elements of piracy is committed with possible political intentions but against private ships, insurers should take into consideration broader context and decide carefully on a case by case basis.

\subsubsection{Persons acting maliciously}

After rise of Somali piratical attacks in 2008, the question of distinction between piracy and persons acting maliciously has been taken into consideration. Namely, it has been argued that behind some of the Somali gangs there were terrorist groups which provoked attacks which lead to the following issue. Could these attacks be categorized as piracy perils or persons acting maliciously perils? For instance, concerning the Hull insurance, under the Institute War and Strikes Clauses HullsTime, clause 1.5. provides coverage for loss or damage to the vessels caused by any terrorist or any person acting maliciously or from a political motive, while piracy is explicitly excluded in clause 5.1.6. Therefore, it seems necessary to tackle the respective issue in order to determine under which clauses should certain attacks with elements of piracy fall within. ${ }^{45}$

When determining the difference between these two perils, several methods can be used. For instance, it can be taken as a general rule that pirates primarily do not have a motivation to destroy the ship they have attacked. Their prior motives are of economical nature which is usually money or valuables, although it is possible that they would damage or destroy the ship especially if their mission was not of success. On the other side, person acting maliciously has different motives other than those of primarily economical nature. ${ }^{46}$ When this difference cannot be made, and one insurance policy covers piracy excluding at the same time similar other acts, one possible approach is to utilize the causation principles established in the case Wayne $v$. Tank and Pump ${ }^{47}$ in order to exclude one coverage. However, this approach is useful when there are two proximate causes, while usually in cases involving piracy and similar acts there is only one cause that could form two different perils. ${ }^{48}$

Another way of solving the issue of distinction between those two acts is to modify the approach set in case of The Grecia Express ${ }^{49}$ which related to persons acting maliciously, and take an approach that damage caused by piratical act will fall under the piracy peril as long as the pirates did not have prior intention of destroying the ship. If piratical act crosses the border and turns primarily into destructive act, for instance after their demand for ransom has been refused, their act should be categorized

45 Gauci, G., op. cit., n. 15, pp. 551-552.

46 Ibid. p. 551-552.

47 United Kingdom Court of Appeal (Civil Division), Wayne Tank \& Pump Co Ltd v. Employers Liability Assurance Corp Ltd., June 7, 1973, [1974] Q. B. 57, https://vpn.pravo.hr/maf/wluk/ app/,DanaInfo=login.westlaw.co.uk + document? $\mathrm{src}=$ doc \&linktype $=$ ref\&context $=5 \& \mathrm{crumb}$-act ion=replace\&docguid=IF11E71E1E42811DA8FC2A0F0355337E9, February 05, 2017.

48 Gauci, G., op. cit., n. 15, p. 551-552.

49 English Commercial Court, Strive Shipping Corporation and Royal Bank of Scotland plc v. Hellenic Mutual War Risks Association (The Grecia Express), March 25, 2002, 2 Lloyd's Rep. 88, 96, http://archive.onlinedmc.co.uk/strive_shipping_v_hwra.htm, February 05, 2017. 
within a peril of person acting maliciously and covered by War and Strikes policy, if there is any. ${ }^{50}$

\subsubsection{Riots}

Same as for politically motivated acts and persons acting maliciously, riot can too represent an act of piracy if its constituent elements are satisfied. Hereby it is crucial to distinguish piracy from riot, since riot is considered to be specific peril that is covered by War and Strikes Clause.

To look for key differentiating elements one should look into applicable national law. For instance, according to English Public Order Act $1986^{51}$ riot exists where 12 or more persons who are present together use or threaten unlawful violence for common purpose and the conduct of them (taken together) is such as would cause a person of reasonable firmness present at the scene to fear for his personal safety. Although the question of whose law is applicable can be resolved by use of choice-of-law rules, in practice that could give rise to certain additional problems especially if applicable law differs from one chosen in marine insurance contract and/or is hard to determine applicable law of foreign law. ${ }^{52}$

\subsection{Definition of piracy in marine insurance law de lege ferenda}

To sum up, after thorough analysis of institute of piracy, following elements can be held as crucial in defining piracy within marine insurance law:

1) act of violence, detention or any act of depredation;

2) committed by the crew or the passengers of a private ship or a private aircraft;

3) committed on sea;

4) private intention;

5) personal gain.

Having that in mind, the author proposes following definition of piracy in context of marine insurance law:

Piracy is an act of violence, detention or any act of depredation committed on the sea with private intention for personal gain by the crew or the passengers of a private ship or private aircraft against another ship or aircraft.

\section{PIRACY-MARINE OR WAR PERIL?}

One of the most discussed matters of piracy in context of marine insurance law is a question of whether piracy should be treated as a marine risk or as a war risk. Answering the respective question has far-reaching consequences. Namely, if piracy is treated as a marine risk it falls within insured marine risks. On the contrary, if it falls within war risk it would be treated as an excluded risk from regular marine insurance

50 Gauci, G., op. cit., n 15, p. 551-552.

51 English Public Order Act 1986, available at: http://www.legislation.gov.uk/ukpga/1986/64/ pdfs/ukpga_19860064_en.pdf.

52 Gotthard Gauci, op. cit., n. 15, pp. 551-552. 
policy and would be covered by War insurance coverage. Throughout the history it fluctuated between both. For providing legal certainty on that matter it is important to firmly decide upon piracy's treatment as a peril and leave the parties to decide whether they would like to include or exclude piracy from their marine insurance policies. In order to provide a satisfying answer to the question of treatment of piracy within marine insurance law, it is important to closely analyse the relevant marine insurance clauses.

Generally, English Marine Insurance Act $1906,{ }^{53}$ is considered to be one of the key documents of marine insurance even nowadays. In its Art 3, piracy was included within its definition of maritime perils: "Maritime perils" means the perils consequent on, or incidental to the navigation of the sea, that is to say, perils of the seas, fire, war perils, pirates, rovers, thieves, captures, seizures, restraints, and detainments of princes and peoples, jettisons, barratry, and any other perils, either of the like kind or which may be designated by the policy. As it can be seen from the quoted definition, Marine Insurance Act 1906 uses a broad understanding of marine risks which also includes piracy.

In relation to cargo insurance, piracy was firstly treated as a marine and subsequently as an all- risk peril in accordance with Marine Insurance Act 1906. That changed after 1937 in the aftermath of the Spanish civil war, when piracy began to be treated as a war risk. ${ }^{54}$ With the issuance of Institute Cargo Clauses in 1982, treatment of piracy changed again. Although piracy was not covered by Institute Cargo Clauses $(B)^{55}$ and Institute Cargo Clauses (C $)^{56}$ that lay on the concept of named perils, it was covered by Institute Cargo Clauses (A). ${ }^{57}$ In clause 6.2. of Institute Cargo Clause (A) piracy was explicitly excluded from War Exclusion Clause which means that it falls within coverage of Institute Cargo Clause (A) as a marine and an all-risk peril. However, due to the rise of piracy incidents off the coast of Somalia in the recent decade, Cargo Piracy Notice of Cancellation was introduced to London Market for the use with the Institute Cargo Clauses in order to enable insurers to give notice of cancellation during the currency of the policy. This means that in the event of insurance covering piracy and/or general average, salvage and sue and labour charges arising from piracy, insurers are allowed to cancel such coverage giving the seven days' notice in writing. Other insurance which has been attached before the cancellation takes effect is not affected, and also such cancellation has an effect of forming the adapted new rate of premium conditions and/or warranties. ${ }^{58}$ Nevertheless, this does not have an impact on categorization of piracy as a marine peril.

Concerning the hull insurance, risk of piracy is usually considered to be a marine risk and can be insured under number of different forms of clauses. That includes

53 English Marine Insurance Act 1906, 8 Edw. 7 c. 41, available at: http://www.legislation.gov. uk/.

54 Dunt, J., Marine Cargo Insurance, Second Edition, New York, 2016, p. 225.

55 Institute Cargo Clauses (B), 1/1/82.

56 Institute Cargo Clauses (C), 1/1/82.

57 Institute Cargo Clauses (A), 1/1/82.

58 Dunt, J., op. cit. n. 54, p. 225. 
1983 Institute Time Clauses Hulls ${ }^{59}$ and 1983 Institute Voyage Clauses ${ }^{60}$ where piracy is explicitly included among named perils that are covered. Piracy is also included in the covered marine risks of 2002/2003 International Hull Clauses,${ }^{61}$ however, some authors suggest that since around 2005, the alternative wording is available to transfer the risk of piracy to the war risk in terms of 2002/2003 International Hull Clauses. ${ }^{62}$

By analysis of Rules of International Group of P\&I clubs, it can be concluded that P\&I clubs have practice to exclude war risks from their coverage. Therefore, since term war risk usually does not and should not include piracy, perils for which P\&I clubs offer insurance are still covered regardless of whether they are caused by act of piracy, unless otherwise agreed by the parties ${ }^{63}$ For instance, if certain pollution claim or crew claim was caused by piracy, they will still be covered by P\&I insurance. ${ }^{64}$

Therefore, as it can be seen from previous analysis, determining whether piracy is maritime or war peril is of utmost importance. Namely, maritime and war perils are nowadays usually treated differently. The most notable difference is that they are covered by the different policies that usually exclude one another. ${ }^{65}$ Taking all

59 Institute Time Clauses Hulls, 1/10/83, clause 6.1.5.

60 Institute Voyage Clauses Hulls, 1/10/83, clause 4.1.5.

61 International Hull Clauses 1/11/03, clause 2.1.5.; Hogg Lindley, R., A Commentary on the International Hull Clauses (01/11/03), $18^{\text {th }}$ November 2003, https://www.ctplc.com/ media/72223/A-Commentary-on-the-International-Hull-Causes.pdf, February 05, 2017.

62 Gauci, G., op. cit., n. 15, p. 544.

63 Britannia, Rules of Class 3, Protection \& Indemnity and List of Correspondents, 2017, $<$ https://www.britanniapandi.com/assets/Uploads/documents/Britannia-Rules-2017-PI.pdf>, February 05, 2017. Rule 25; Gard, Rules 2017, <http://www.gard.no/web/publications/ document/781871/gard-rules-2017>, February 05, 2017., Rule 58; Japan P\&I club, Rules of Association 2017, <https://www.piclub.or.jp/eng_news/rules_articles/rules/>, February 05, 2017., Rule 35; The London P\&I Club, P\&I Rules 2017-2018, <https://www.londonpandi.com/ pandi/rules/>, February 05, 2017, Rule 15; North of England P\&I Club, P\&I Rules 2017, <http:// www.nepia.com/media/638701/NORTH-PI-Rules-2017-18-.pdf $>$, February 05, 2017, Rule 24; Shipowners' Club, Rules 2017, <https://www.shipownersclub.com/media/2017/02/Club Rules2017.pdf $>$, February 05, 2017, Rule 25; Skuld, P\&I Rules 2017, <https://www.skuld. com/Documents/Library/Rules_Terms_Conditions/2017/Skuld_PandI_Rules-2017_web.pdf>, February 05, 2017., p. 58; Steamship Mutual, Rules and List of Correspondents, $<$ https://www. steamshipmutual.com/Downloads/Rules-and-Maps-/2017\%20Steamship\%20Mutual\%20 Rules\%20interactive.pdf $>$, February 05, 2017., Rule 21; The American Club, By-Laws, Rules and List of Correspondents 2017/2018, <http://www.american-club.com/page/rules $>$, February 05, 2017, Rule 3, Section 1; Swedish Club, Rules for P\&I Insurance 2017/2018, <http://www. swedishclub.com/media_upload/files/Publications/TSC\%20PI-FDD\%20Rules_2017-18\%20 web.pdf>, February 05, 2017., Rule 11, Section 5; United Kingdom P\&I Club, 2017 Rules of UKE, <https://www.ukpandi.com/fileadmin/uploads/uk-pi/Documents/2017/Brochures/Rules/ rule_section_only_version_2.pdf>, February 05, 2017, Rule 5E; West of England, 2017 Rule Book, <http://www.westpandi.com/globalassets/rulebook/2017.pdf>, February 05, 2017, Rule 14.

64 United Kingdom P\&I Rulebook, Rule 5E.

65 At the beginning of development of marine insurance law there was no difference between maritime and war perils. They have been considered jointly as threats that endanger security of property on sea and were assured by the same insurance contracts. Through time due to worsened political relations and frequent wars, concept of unique insurance of maritime and war risks had been abandoned. Pavić, D., op. cit. n. 3, p. 463-463. 
the above mentioned into account, it would be plausible to generally treat piracy as a maritime peril. Besides that, distinction between marine and war perils has some further consequences, such as the legality of payment of ransoms. Analysis on that matter will be given in the following section.

\section{RANSOM PAYMENTS AS AN INSURABLE RISK}

\subsection{Ransom payment in general}

Piracy has become a lucrative "business". ${ }^{66}$ Therefore, in order to gain certain economic benefit, it is common that pirate attacks are followed by a ransom demand.

Until now, in this paper piracy was observed as a risk that occurs in marine insurance. From this perspective, it was firstly important to provide a proper definition of piracy as an institute and then to position a peril of piracy within maritime or war risks. However, when talking about ransom payment it would be necessary to analyse it as an insured damage.

In order to do so, before going into any further analyse of ransom payments it is important to determine whether ransom payments are even legal and allowed within certain legal orders.

\subsection{Legality of ransom payments}

There are lots of ongoing discussions about legality of ransom payments and their treatment within legal orders. Different States have dealt differently with this issue. However, it is a fact that ransoms are being paid to pirates in massive amount. ${ }^{67}$

Following the abolishment of Ransom Act $1782^{68}$ by the 1864 Naval Prize Act, ${ }^{69}$ English law, does not consider ransom payments apriori illegal. However, as it was held in United Kingdom Court of Appeal - Commercial Court case Mahonia Ltd. v JP Morgan Chase Bank $k^{70}$ contract that was generally lawful but entered into for unlawful purpose could not be enforced in front of English court, even though its illegality was alleged under the foreign law. This leads to another question of which law should be looked into when deciding upon legality of certain ransom payments? Should the governing law when deciding of legality of certain ransom payment be the law of

66 Yvonne M. Dutton, Jon Bellish, op. cit. n. 1, pp. 305-307.

67 Average ransom payments to Somali pirates have increased sevenfold from 2007 to 2011, turning piracy into a multi-million dollar business. FCO figures show average ransoms rising from around \$600,000 in 2007 to close to \$5m in 2011. United Kingdom Foreign Affairs Committee, Piracy off the Coast of Somalia, 2010-2012, H.C: 1318, pp. 55.

68 English Ransom Act 1782, Act 22 Geo III c 25.

69 English Naval Prize Act 1864, 27 \& 28 Vic. c. 25, available at: http://www.legislation.gov.uk/ ukpga/Vict/27-28/25/contents.

70 United Kindgdom, Court of Appeal - Commercial Court, Mahonia Ltd. v JP Morgan Chase Bank, July 30, 2003, [2003] EWHC 1927 (Comm), available at: http://high-court-justice.vlex. co.uk/vid/2002-folio-1400-52637646 
the contract, the law of the place of payment or the law of the flag? ${ }^{71}$ This issue was touched upon in English case Royal Boskalis Westminster N.V. And Others v. Trevor Rex Mountain and Others ${ }^{72}$ where it was held that payments made for the release of the subject matter of insurance were not part of insured adventure and that finalization agreement was not an unlawful act under English law, nor under the law of Iraq, where that act was performed, nor indeed under any other law. If the conclusion of the Finalisation Agreement had been unlawful within the meaning of the warranty, the Joint Venture would have been protected by the provision "so far as the assured can control the matter". ${ }^{73}$ Provision so far as the assured can control the matter implies warranty of legality from Sec 41 of Marine Insurance Act 1906 according to which there is an implied warranty that the adventure insured is a lawful one, and that, so far as the assured can control the matter, the adventure shall be carried out in a lawful manner.

However, regardless of the previous, if certain act with elements of piracy would fall within definition of United Kingdom Terrorism Act $2000,{ }^{74}$ payment of ransom would be considered as illegal. According to Art 15(3) of Terrorism Act 2000 a person commits an offence if he provides money or other property, and knows or has reasonable cause to suspect that it will or may be used for the purposes of terrorism. Having in mind the aforementioned discussion on piracy and similar acts, piracy and terrorism could easily overlap. Especially emphasized should be the importance and necessity of differentiating piracy from similar acts, particularly if the motivation and intention are the only distinguishing elements thereof. Therefore, it can be concluded that the payment of ransom is not regarded as illegal as long as it is not paid to terrorism organization or relating to any political purposes. ${ }^{75}$

So, in order for certain ransom payments made to pirates to be allowed, it can be concluded that it must be legal, reasonable and expended for the purpose of minimizing a damage covered by the policy. ${ }^{76}$

\subsection{Justification of ransom payments within marine insurance law}

As it can be seen from the above, ransom payment is not a priori excluded as a recoverable expense in marine insurance. However, in order for it to be recovered, it must be paid for the purpose of releasing a ship (or cargo, or passengers) from pirates and it has to fulfil conditions of legality, reasonableness and usage for the purpose

71 Gotthard Gauci, op. cit. n. 15, pp. 559.

72 United Kingdom Supreme Court of Judicature, Royal Boskalis Westminster N.V. And Others v. Trevor Rex Mountain and Others [1997] EWCA Civ 1140 (28th February, 1997).

73 Ibid.

74 United Kingdom Terrorism Act 2000, c.11, available at: http://www.legislation.gov.uk/ ukpga/2000/11/contents.

75 X. Xin, Research on the Nature of the Ransom Paid to Somali Pirates and Its Effects, master thesis, University of Oslo, Faculty of Law, available at: https://www.duo.uio.no/bitstream/ handle/10852/22814/MasterxThesisx-xCandidatenbr_5043.pdf?sequence=1, p. 17.

76 Gotthard Gauci, op. cit., n. 15, p. 552. 
of minimizing a damage covered by the policy. ${ }^{77}$ Still there is an open question of justification of ransom payments within marine insurance law, since it is usually not a risk which is expressly covered by the policies.

In most cases, it is likely that a ship-owner will pay the demanded ransom amount. However, it does not always have to be the case, especially in the case of cargo carrying ship when there is more than one subject that would have the interest to pay off the ransom. In that situation, the issue is whether a ransom payment can constitute a general average act? Sec 66(2) of Marine Insurance Act 1906 states that there is a general average act where any extraordinary sacrifice or expenditure is voluntarily and reasonably made or incurred in time of peril for the purpose of preserving the property imperilled in the common adventure. When ransom has been paid in order to preserve a ship and its cargo and people, it could certainly be considered to be general average. The only issue might be the question of voluntariness of the payment. Thus, if we presume that ransom payment can be treated as a general average, according to Sec 66(4) of Marine Insurance Act 1906 - in the case of general average sacrifice the assured may recover from the insurer in respect of the whole loss without having enforced his right of contribution from other liable to contribute. Therefore, when this is the case, the assured person who paid the ransom could claim the entire amount on the basis of his policy, while, later on, the insurer would be subrogated in relation to other interested subjects on the basis of general average. ${ }^{78}$

On the other hand, ransom payment could also be observed as a sue and labour charge. In general, the assured and their agents have the obligation to take such measures as it may be reasonable for the purpose of averting or minimising a loss, ${ }^{79}$ which ransom certainly is. Whether or not the taken measures were reasonable, depends on particular situation and on the ratio of demanded ransom and value of vessel..$^{80}$ Marine insurance clauses usually contain sue and labour clause. For instance, sue and labour clause is contained in clause 9 of 2003 International Hull Clauses. But even if sue and labour clause is not included in a certain policy, the insurer still has an obligation to reimburse the assured for measures taken in order to avert or minimize loss on basis of marine insurance legislation which usually contains sue and labour clause. ${ }^{81}$ For instance, in case Emperor Goldmining CO. Ltd. v. Switzerland General Ins. Co. Ltd. ${ }^{82}$ Supreme Court of New South Wales stated that the mere absence of sue and labour clause does not mean that costs that were caused in order to avert or minimize loss were not recoverable from the insurer. Thus, according to the statutory obligations, costs were properly recoverable from the policy. ${ }^{83}$

77 Ibid., p. 552.

78 Soady, R., A Critical Analyses of Piracy, Hijacking, Ransom Payments, and Whether Modern London Insurance Market Clauses Provide Sufficient Protection for Parties Involved in Piracy for Ransom, Journal of Maritime Law \& Commerce, Vol. 44, No. 1, January, 2013, p. 17-18.

79 Marine Insurance Act, Sec 78(4).

80 Soady, R., op. cit. n. 77, p. 17-18.

81 Ibid. p. 18.

82 Supreme Court of New South Wales, case Emperor Goldmining CO. Ltd. v. Switzerland General Ins. Co. Ltd. [1964] 1 Lloyd's Rep. 348

83 Hodges, S., Cases and Materials on Marine Insurance Law, London, 1999, p. 789-790. 
Further on, considering P\&I club insurance there is also a possibility that ransom may be recovered at the discretion of boards of the clubs under the omnibus provision regardless of general average and sue and labour rules. ${ }^{84}$

Therefore, when analysing ransom payment, it can be clearly perceived as both sue and labour or general average. However, instead of going into any further debate on deciding whether ransom payments should be justified as general average or sue and labour, it should be concluded that piracy ransom payment should be treated as an insured damage sui generis. In lack of special provisions for that institute, both general average rules and sue and labour rules should reasonably apply depending on a certain case.

\section{CONCLUSION}

After the afresh rise of piracy in 2005 , there are ongoing discussions on that matter. From the perspective of marine insurance law, there are still several unresolved questions considering treatment of piracy. One of them is certainly a definition of piracy, as a starting point for any further analysis. As it can be seen from the above text, there is no unique definition of piracy. On the contrary, there are numerous different understandings that arise from legislation, practice and case law. However, in order to be able to serve for the purposes of marine insurance law, a proper definition of piracy must adjust to specific nature of this area of law. After a thorough analysis on this matter, following definition is proposed in this paper:

Piracy is an act of violence, detention or any act of depredation committed on the sea with private intention for personal gain by the crew or the passengers of a private ship or private aircraft against another ship or aircraft.

Proposed definition is based on, until now, accepted understandings of piracy whereas having in mind particularities of marine insurance law.

The proposed definition is based on, until now, accepted understandings of piracy whereas having in mind particularities of marine insurance law.

Further on, the treatment of piracy as a peril within marine insurance is also disputable. Throughout the history, treatment of piracy has fluctuated between marine and war risk. However, considering the nature of the act of piracy and marine insurers practice, piracy should rather be considered as a marine risk.

Finally, the question of ransom payments is one of the most controversial ones regarding the institute of piracy, starting from the issue of its legality. After a thorough research on that matter, however, it can be stated that pirate ransom payments are not illegal as long as they fulfil certain conditions of legality; reasonability and usage for the purpose of minimizing a damage covered by the policy. Further on, if pirate ransom tends to be considered as legal and recoverable from marine insurance policies, the question of justification of that kind of payments is being raised. There are two possible solutions regarding that matter - to treat ransoms as general average or as a sue and labour. However, the author suggests the third solution of treatment

84 United Kingdom P\&I club, Piracy FAQ's, <https://www.ukpandi.com/fileadmin/uploads/uk-pi/ Latest_Publications/Circulars/Piracy\%20FAQs.pdf>, February 05, 2017. 
of pirate ransom payments - as a sui generis insured damage or loss, whereas rules for general average and sue and labour should apply adequately, depending on the specific circumstances of a certain case.

\section{BIBLIOGRAPHY}

1. Azubuike, L., International Law Regime Against Piracy, Annual Survey of International and Comparative Law, Vol 15, No 1, 2010, pp 43-59

2. Bantekas, I., Nash, S., International Criminal Law, 2nd ed, London, 2003

3. de Souza, P., Piracy in the Graeco-Roman World, Cambridge, 2002

4. Dunt, J., Marine Cargo Insurance, Second Edition, New York, 2016

5. Dutton, Y., M., Bellish, J., Refusing to Negotiate: Analyzing the Legality and Practicality of a Piracy Ransom Ban, Cornell International Law Journal, Vol. 47, pp. 299-329

6. East, E., H., A Treatise of the Pleas of the Crown, Vol. II, Philadelphia, 1806

7. Gauci, G., Piracy and its Legal Problems: With Specific Reference to the English Law of Marine Insurance, Journal of Maritime Law \& Commerce, Vol. 41, No. 4, October, 2010, pp 541-560

8. Gosse, P., The History of Piracy, New York, 1934

9. Guilfoyle, D., Political Motivation and Piracy: What History Doesn't Teach Us About Law, Blog of the European Journal of International Law, June 17, 2013, available at: http:// www.ejiltalk.org/political-motivation-and-piracy-what-history-doesnt-teach-us-about-law/ (accessed: 05.02.2017.)

10. Hodges, S., Cases and Materials on Marine Insurance Law, London, 1999

11. Hodgkison, S., I., The Governing International Law on Maritime Piracy, in: Scharf, M., P. (ed.), Newton, M (ed.)., A., Sterio, M. (ed.), Prosecuting Maritime Piracy: Domestic Solutions to International Crimes, 2015, pp. 13-32

12. Hogg Lindley, R., A Commentary on the International Hull Clauses (01/11/03), available at: https://www.ctplc.com/media/72223/A-Commentary-on-the-International-Hull-Causes.pdf

13. Honnibal, A., N., The 'Private Ends' of International Piracy: The Necessity of Legal Clarity in Relation to Violent Political Activists, International Criminal Database, Brief 13, October 2015, available at: http://www.internationalcrimesdatabase.org/upload/ documents/20151102T100953-Honniball\%20ICD\%20Brief.pdf

14. Johnson, D., H., N., Piracy in Modern International Law, Transactions of the Grotius Society, Vol. 43, Problems of Public and Private International Law, Transactions for the Year 1957 (1957), pp. 63-85

15. Matsuda, M., Wang Chung-Hui, M., Questionnaire No. 6: Piracy.” The American Journal of International Law, vol. 20, no. 3, 1926, pp. 222-229.

16. Passman, M., H., Interpreting Sea Piracy Clauses in Marine Insurance Contracts, Journal of Maritime Law \& Commerce, vol. 40, No. 1, January, 2009, pp 59-88

17. Pavić, D., Pomorsko imovinsko pravo, Split, 2006

18. Pavliha, M., Overview of Marine Insurance Law, IMO International Maritime Law Institute, Malta, 7th - 10th January 2013, available at: http://www.google.hr/url?sa=t\&rc $\mathrm{t}=\mathrm{j} \& \mathrm{q}=\&$ esrc $=\mathrm{s} \&$ source $=$ web \& $\mathrm{cd}=3 \& \mathrm{ved}=0$ ahUKEwjciNmN-YrSAhWqIJoKHRpkBAQFggpMAI\&url=http $\% 3 \mathrm{~A} \% 2 \mathrm{~F} \% 2 \mathrm{Fwww}$. dpps-mlas.si\%2Fwp-content $\% 2 \mathrm{Fupload}$ s\%2F2012\%2F12\%2FOverview-of-Marine-Insurance-Law-Prof.-dr.-Marko-Pavliha. doc\&usg=AFQjCNF73RTdPBYnbIhDcRUDbEcUVAHu4Q

19. Pospišil, M., Somalsko piratstvo - od vojnopomorskih operacija do naoružanja brodova, Zbornik radova Pravnog fakulteta u Splitu, yr. 49., no 1/2012, pp 59-96 
20. Pyeatt Menneffe, S., The Case of the Castle John or Greenbeard the Pirate?: Environmentalisam, Piracy and the Developement of International law, California Western International Law Journal, Vol 24, No 1, Fall 1993, pp 1-16

21. Ronzitti, N., The Law of the Sea and Use of Force Against Terrorist Activities, in: Ronzitti, N (ed), Maritime Terrorism and International Law, Dordrecht, 1990, pp 1-15

22. Rubin, A.P., The Law of Piracy, Newport, 1988

23. Xin, X., Research on the Nature of the Ransom Paid to Somali Pirates and Its Effects, master thesis, University of Oslo, Faculty of Law, available at: https://www.duo.uio.no/bitstream/ handle/10852/22814/MasterxThesisx-xCandidatenbr_5043.pdf?sequence=1

\section{LEGAL SOURCES}

1. Convention for the Suppression of Unlawful Acts against the Safety of Maritime Navigation, March 10, 1988, 27 ILM 668 (1988); 1678 UNTS 221 available at: http://www.un.org/en/sc/ ctc/docs/conventions/Conv8.pdf

2. English Ransom Act 1782, Act 22 Geo III c 25

3. English Naval Prize Act 1864, 27 \& 28 Vic. c. 25, available at: http://www.legislation.gov. uk/ukpga/Vict/27-28/25/contents

4. English Marine Insurance Act 1906, 8 Edw. 7 c.41, available at: http://www.legislation.gov. uk/

5. English Public Order Act 1986, available at: http://www.legislation.gov.uk/ukpga/1986/64/ pdfs/ukpga_19860064_en.pdf

6. United Kingdom Terrorism Act 2000, c.11, available at: http://www.legislation.gov.uk/ ukpga/2000/11/contents

7. United Nations Convention on the High Sea, 29 April 1958, 13 UST 2312; 450 UNTS 11, available at: http://www.gc.noaa.gov/documents/8 1 1958 high seas.pdf

8. United Nations Convention on the Law of the Sea, 10 December 1982, 1833 UNTS 3; 21 ILM 1261 (1982), available at: http://www.un.org/depts/los/convention_agreements/texts/ unclos/unclos_e.pdf

\section{CASE LAW}

1. Belgium Cour de Cassation, case Castle John and Nederlandse Stichting Sirius v. NV Mabeco and NV Parfin, December 19, 1988, 77 ILR 537

2. English Commercial Court, Strive Shipping Corporation and Royal Bank of Scotland ple v Hellenic Mutual War Risks Association (The Grecia Express), March 25, 2002, 2 Lloyd's Rep. 88, 96, available at: http://archive.onlinedmc.co.uk/strive shipping_v hwra.htm

3. Supreme Court of the United States, case Institute of Cetacean Research v Sea Shepherd Conservation Society, Notice of Filing of Petition for Certiorari, April 30, 2015, available at: http://cdn.ca9.uscourts.gov/datastore/general/2015/05/05/12-35266\%20Cert\%20Notice.pdf

4. United Kindgdom, Court of Appeal - Commercial Court, Mahonia Ltd. v JP Morgan Chase Bank, July 30, 2003, [2003] EWHC 1927 (Comm), available at: http://high-court-justice. vlex.co.uk/vid/2002-folio-1400-52637646

5. United Kingdom Court of Appeal (Civil Division), Wayne Tank \& Pump Co Ltd v Employers Liability Assurance Corp Ltd., June 7, 1973, [1974] Q.B. 57, available at: https://vpn.pravo. $\mathrm{hr} / \mathrm{maf} /$ wluk/app/,DanaInfo=login.westlaw.co.uk+document? $\mathrm{src}=$ doc\&linktype=ref\&conte $\mathrm{xt}=5 \&$ crumb-action $=$ replace $\&$ docguid $=$ IF11E71E1E42811DA8FC2A0F0355337E9

6. United States Court of Appeals for the Ninth Circuit, case Institute of Cetacean Research v Sea Shepherd Conservation Society, available at: https://www.ca9.uscourts.gov/content/ view.php?pk_id=0000000655 (accessed: 05.02.2017.)

7. United States Court of Appeals for the Ninth Circuit, case Institute of Cetacean Research $v$ Sea Shepherd Conservation Society, Opinion of Judge Kozinski, from February 25, 2013, available at: http://cdn.ca9.uscourts.gov/datastore/general/2013/02/25/1235266.pdf (accessed: 05.02.2017.) 


\section{OTHER CLAUSES}

1. Institute Cargo Clauses (A), 1/1/82

2. Institute Cargo Clauses (B), $1 / 1 / 82$

3. Institute Cargo Clauses (C), $1 / 1 / 82$

4. Institute Time Clauses Hulls, 1/10/83

5. Institute Time Clauses - Hulls, 1/11/95

6. Institute Voyage Clauses Hulls, 1/10/83

7. Institute War and Strikes Clauses, Hulls - time, 1/11/95

8. International Hull Clauses 1/11/03

\section{RULEBOOKS}

1. Britannia, Rules of Class 3, Protection \& Indemnity and List of Correspondents, 2017, available at: https://www.britanniapandi.com/assets/Uploads/documents/Britannia-Rules2017-PI.pdf

2. Gard, Rules 2017, available at: http://www.gard.no/web/publications/document/781871/ gard-rules-2017

3. Japan P\&I club, Rules of Association 2017, available at: https://www.piclub.or.jp/eng_news/ rules_articles/rules/

4. North of England P\&I Club, P\&I Rules 2017, available at: http://www.nepia.com/ media/638701/NORTH-PI-Rules-2017-18-.pdf

5. Shipowners' Club, Rules 2017, available at: https://www.shipownersclub.com/ media/2017/02/Club_Rules2017.pdf

6. Skuld, P\&I Rules 2017, available at: https://www.skuld.com/Documents/Library/Rules Terms_Conditions/2017/Skuld_PandI_Rules-2017_web.pdf

7. Steamship Mutual, Rules and List of Correspondents 2017, available at: https://www. steamshipmutual.com/Downloads/Rules-and-Maps-/2017\%20Steamship\%20Mutual\%20 Rules\%20interactive.pdf

8. Swedish Club, Rules for P\&I Insurance 2017/2018, available at: http://www.swedishclub. com/media_upload/files/Publications/TSC\%20PI-FDD\%20Rules_2017-18\%20web.pdf,

9. The American Club, By-Laws, Rules and List of Correspondents 2017/2018, available at: http://www.american-club.com/page/rules

10. The London P\&I Club, P\&I Rules 2017-2018, available at: https://www.londonpandi.com/ pandi/rules/

11. United Kingdom P\&I Club, 2017 Rules of UKE, available at: https://www.ukpandi.com/ fileadmin/uploads/uk-pi/Documents/2017/Brochures/Rules/rule_section_only_version_2. pdf

12. United Kingdom P\&I Rulebook, Rule 5E, available at: https://www.ukpandi.com/fileadmin/ uploads/uk-pi/Documents/2010RulesandCorrespondents_01.pdf

13. West of England, 2017 Rule Book, available at: http://www.westpandi.com/globalassets/ rulebook/2017.pdf

\section{REPORTS}

1. ICC International Maritime Bureau Piracy and Armed Robbery Against Ships Annual Report, 1 January - 31 December 2007

2. In Re a Reference under the Judicial Committee Act, 1833, In Re Piracy Jure Gentium, The American Journal of International Law, vol. 29, no. 1, 1935, pp. 140-150.

3. United Kingdom Foreign Affairs Committee, Piracy of the Coast of Somalia, 2010-2012, H.C. 1318

\section{DICTIONARIES}

1. Black's Law Dictionary Free Online Legal Dictionary 2nd Ed., available at: http:// thelawdictionary.org/piracy/ 


\section{WEB PAGES}

1. https://www.icc-ccs.org/piracy-reporting-centre

2. United Kingdom P\&I club, Piracy FAQ's, available at: https://www.ukpandi.com/fileadmin/ uploads/uk-pi/Latest_Publications/Circulars/Piracy\%20FAQs.pdf 


\section{Dino Gliha*}

Sažetak

\section{PIRATSTVO U SVJETLU PRAVA POMORSKOG OSIGURANJA S OSVRTOM NA OTKUPNINE}

Nakon napada somalijskih pirata u 2008. godini, piratstvo je steklo značajnu popularnost u znanstvenoj literaturi. Međutim, neovisno o brojnim raspravama i znanstvenim istraživanja koja su se provela na temu piratstva kroz zadnjih desetak godina, neka bitna pitanja ostala su i dalje nerazriješena, počevši od same definicije piratstva. U analizi piratstva iz perspektive pomorskog osiguranja, potrebno je uzeti $\mathrm{u}$ obzir određene specifičnosti prava pomorskog osiguranja. Međunarodnopravna, kaznenopravna i druge postojeće definicije piratstva nisu zadovoljavajuće za potrebe prava pomorskog osiguranja. Stoga je prije svega potrebno pronaći prikladno shvaćanje instituta piratstva u kontekstu pomorskog osiguranja. Nakon toga, moguće je prijeći na određena druga sporna pitanja piratstva u pomorskom osiguranju. Jedno od njih svakako je kategorizacija piratstva kao osiguranog rizika tj. smatra li se piratstvo pomorskim osiguranim rizikom ili ratnim osiguranim rizikom. Iako je kroz povijesni razvoj tretman piratstva fluktuirao između jednog i drugog shvaćanja, uzimajući u obzir prirodu piratstva te praksu osiguratelja, piratstvo bi se trebalo smatrati pomorskim osiguranim rizikom. Nadalje, jedno od najviše raspravljanih pitanja u modernog piratstva su otkupnine i mogu li se one uopće smatrati pravno dopuštenima. Analizom sudske prakse i prakse osiguratelja može se zaključiti da se naknađivanje otkupnina iz pomorskih polica osiguranja može ipak smatrati pravno opravdanim pri čemu bi se otkupnina trebala tretirati kao sui generis osigurani slučaj.

Ključne riječi: pomorsko osiguranje, piratstvo, definicija piratstva, pomorski osigurani rizici, otkupnina.

Zussamenfassung

\section{PIRATERIE IM LICHTE DER SEEVERSICHERUNG UNTER BERÜCKSICHTIGUNG DES LÖSEGELDS}

Nach dem Angriff der somalischen Piraten im Jahr 2008, hat Piraterie in wissenschaftlicher Literatur an Bedeutung bekommen. Ungeachtet zahlreicher Diskussionen und wissenschaftlicher Forschungen über Piraterie in den letzten zehn Jahren, sind manche wesentliche Fragen trotzdem unbeantwortet geblieben,

* Dino Gliha, Legal Trainee at Attorney at Law; dino.gliha@gmail.com. 
beispielsweise, die Frage, wie man Piraterie definieren sollte. Bei der Analyse der Piraterie aus der Perspektive der Seeversicherung muss man bestimmte Besonderheiten des Seeversicherungsrechts in Betracht ziehen. Die völker-und strafrechtlichen sowie auch andere Definitionen der Piraterie eignen sich nicht für das Seeversicherungsrecht. Deshalb ist es vor allem notwendig, das Rechtsinstitut der Piraterie im Kontext der Seeversicherung aufzufassen. Erst danach kann man versuchen, andere umstrittene Fragen der Piraterie im Bereich der Seeversicherung zu beantworten. Eine dieser Fragen ist bestimmt die Kategorisierung der Piraterie als versichertes Risiko, beziehungsweise, die Frage, ob Piraterie als das durch die See- oder durch die Kriegsversicherung versicherte Risiko angesehen werden sollte. Obwohl in der Geschichte der Begriff der Piraterie zwischen diesen zwei Auffassungen schwankte, wird in dieser Arbeit die Ansicht vertreten, dass man aufgrund der Natur der Piraterie und der Praxis des Versicherers die Piraterie als das durch die Seeversicherung versicherte Risiko ansehen sollte. Des Weiteren stellt die Frage des Lösegelds eine der meist diskutierten Fragen im Bereich der modernen Piraterie dar, insbesondere bezüglich dessen, ob das Lösegeld überhaupt rechtlich zulässig ist. Aus der Analyse der Rechtsprechung und der Praxis des Versicherers kann man schließen, dass der Ersatz vom Lösegeld aufgrund eines Seeversicherungsscheins trotzdem rechtlich zulässig ist, wobei man das Lösegeld als einen sui generis versicherten Fall behandeln sollte.

Schlüsselwörter: Seeversicherung, Piraterie, Definition der Piraterie, die durch die Seeversicherung versicherten Risiken, Lösegeld.

Riassunto

\section{LA PIRATERIA NEL DIRITTO ALL'ASSICURAZIONE MARITTIMA CON ATTENZIONE PER I RISCATTI}

Dopo l'attacco dei pirati somali nel 2008, la pirateria è divenuta alquanto popolare nella letteratura scientifica. Tuttavia, indipendentemente dal numero di diatribe e di ricerche scientifiche condotte al riguardo negli ultimi dieci anni, alcune importanti questioni sono rimaste irrisolte, a partire dalla definizione stessa di pirateria. Nell'analisi della pirateria da un punto di vista dell'assicurazione marittima, occorre prendere in considerazione determinate peculiarità del dritto all'assicurazione marittima. Le definizioni di pirateria offerte dal diritto internazionale, piuttosto che dal diritto penale o da altre branche, non soddisfano le esigenze del diritto all'assicurazione marittima. Pertanto, anzi tutto, si rende necessario individuare un'interpretazione adeguata dell'istituto della pirateria nel contesto dell'assicurazione marittima. Successivamente, è possibile passare ad altre questioni controverse della pirateria nell'assicurazione marittima. Una di queste questioni sicuramente è data dalla categorizzazione della pirateria alla stregua di un rischio assicurativo; precisamente 
capire se la pirateria vada intesa quale rischio previsto nell'assicurazione marittima oppure si tratti di un rischio assicurato di guerra. Benché nel corso del tempo il trattamento della pirateria è rimbalzato dall'una all'altra categorizzazione, tenendo conto della natura della pirateria e la prassi degli assicuratori, la pirateria andrebbe intesa quale rischio previsto nell'assicurazione marittima. Ancora, una delle questioni più dibattute relative alla pirateria moderna è quella dei riscatti ed in particolare se questi siano ammissibili sotto il profilo giuridico. Analizzando la giurisprudenza e la prassi degli assicuratori, si può concludere che il rimborso del pagamento del riscatto possa considerarsi giustificato, ritenendo il riscatto quale un'ipotesi assicurata sui generis.

Parole chiave: assicurazione marittima, pirateria, definizione di pirateria, rischi coperti dall'assicurazione marittima, riscatto. 